\title{
Improving the Quality of Life for the Elderly with Degenerative Diseases through to the Charitas Group Virtual Health Education Program during the Pandemic of the COVID-19 Wilma Hannie Danie1 ${ }^{1}$, Chairil Anwar ${ }^{2,3,5 *}$, Nur Alam Fajar ${ }^{3}$, Rico Januar Sitorus ${ }^{3,5}$, Ahmad Ghiffari 4,5 \\ ${ }^{1}$ Master Program of Public Health, Faculty of Public Health, Universitas Sriwijaya, Palembang, Indonesia \\ ${ }^{2}$ Faculty of Medicine, Universitas Sriwijaya, Palembang, Indonesia \\ ${ }^{3}$ Faculty of Public Health, Universitas Sriwijaya, Palembang, Indonesia \\ ${ }^{4}$ Faculty of Medicine, Universitas Muhammadiyah, Palembang, Indonesia \\ ${ }^{5}$ Faculty of Environment, Graduate School, Universitas Sriwijaya, Palembang, Indonesia
}

\author{
A R T I C L E I N F O \\ Keywords: \\ Advance Technology \\ Hypertension and Diabetes \\ Online education \\ Old age \\ SARS-CoV-2 \\ *Corresponding author: \\ Chairil Anwar \\ E-mail address: \\ chairil53@fk.unsri.ac.id
}

All authors have reviewed and approved the final version of the manuscript.

https://doi.org/10.32539/bsm.v5i8.389

\begin{abstract}
A B S T R A C T
Background: In the era of the COVID-19 pandemic, various problems were experienced by the elderly, especially those with degenerative diseases, as the population most at risk of being exposed to COVID-19. The elderly are vulnerable to decreased physical, mental and social health; therefore, a new and effective strategy is needed to improve healthy living behavior in this population. This study aimed to analyze the effect of the Charitas Group virtual health education program on improving the quality of life of the elderly with degenerative diseases in the era of the COVID-19 pandemic. Methods: The One Group Pretest-Posttest Pre-Experimental study was with a sample of 33 patients selected by purposive sampling in May - July 2021. The data collection was taken using the World Health Organization Quality of Life - Bref (WHOQOL-Bref) form, translated and validated into Bahasa Indonesia. The data was then compared before and after the intervention and analyzed using the Paired Samples T-Test. Results: The T-Test showed a significant difference between the pre-test and post-test results (p-value $0.041<0.05)$. At the same time, the other $\mathrm{T}$-Test results showed a significant influence on the quality of life of the elderly in the specific domains, namely: Psychological (p-value 0.025), Social Relationship (p-value 0.033) and Environmental (p-value 0.034). Conclusions: The Charitas Group virtual health education program significantly influences the quality of life of elderly people with degenerative diseases in the COVID-19 pandemic era.
\end{abstract}

\section{Introduction}

On December 31, 2019, the WHO China Country Office reported pneumonia of unknown etiology in Wuhan City, China, identified the case as a novel of coronavirus ${ }^{1}$. The pneumonic pandemic has a significant impact on the as elderly's health during isolation and lockdown. Physical inactivity or exercising at home can cause muscle weakness, physical decline, and an increase in the risk of falling; moreover, lack of cognitive stimulus obtained from socialization and contact with the broader world can exacerbate cognitive impairment and behavioral symptoms of dementia elderly ${ }^{2}$. When faced with the challenge of being socially isolated as the elderly, they are especially vulnerable to rapid decline ${ }^{3}$.

The elderly patients suffering from degenerative diseases are at more significant impact from isolation, loneliness, or depression ${ }^{3}$. Hypertension and diabetes already have a higher risk of depression than the younger population and are often not detected in the elderly group 4,5 . Their ability to control their blood 
sugar levels can be influenced by their fear of contracting COVID-19, and avoiding hospitalization because other conditions necessitate treatment will cause tremendous psychological stress ${ }^{6}$. Pain and anxiety were the most frequently reported problems regarding the quality of life in the elderly with chronic degenerative diseases in China (17.6 percent) 7 . The limited access to clinical services during the quarantine period may have resulted in a lack of patient compliance in taking degenerative medicine prescribed by doctors ${ }^{8}$.

Various problems experienced by the elderly during the isolation period require health intervention to improve physical activity and healthy behavior ${ }^{9}$. The Charitas Group, a health institution consisting of six hospitals and three clinics in various regions in Indonesia, simultaneously implements health promotion programs in virtual health education. As part of a current health promotion campaign, a digitalbased approach was used to communicate between the facilitators and all members daily via video conference Zoom, YouTube, and WhatsApp groups. It employs technology and various brain gym, physical activity, elearning, and health meditation to achieve its goals.

\section{Methods}

This research was conducted at the Senior Citizens Virtual Club under the supervision of the Charitas Group Hospitals. Data collection was carried out two times before and after the intervention, from May to July 2021. The total sampling size was 250 respondents who were all older people with degenerative diseases, resided in various provinces in Indonesia.

The One Group Pretest-Posttest Pre-Experimental design study had several criteria. The study used total purposive sampling as the sampling method. The inclusion factors such as age $\geq 60$ years, minimum education of junior high school/equivalent, were able to use digital applications on the device, had audiovisual capabilities and could communicate effectively both orally and in writing. The exclusion criteria in the study were the pre-elderly age, healthy condition, or any diseases other than the degenerative ones, and the elderly never participated in the club activities.

The study commenced by describing the objectives of the study to the respondents via WhatsApp. The respondents who agreed were asked to fill the digital WHOQOL-BREF in the Indonesian version questionnaire10. The questionnaire consisted of 26 questions: two general questions relating to the respondents' perceptions of their quality of life, satisfaction in life and health condition; 4 domains such as the physical domain consisted of 7 questions; psychological domain consisted of 6 questions; social relationships domain consisted of 3 questions, and environmental domain consisted of 8 questions. Every question scored from 1 to 5 . The total score of every domain was calculated and transformed by using the transformation table with a scale of 0-100.

The total score of every domain was examined by using the Kolmogorov-Smirnov normality test. When the data found in the study were normally distributed (p-value $>0.05)$, then the parametric statistical tests were carried out using the Paired Samples T-Test. Brain gym, physical activity, e-learning, health meditation, group discussion, and music were among the intervention offered at the Senior Citizens Virtual Club for one month study. The Universitas Sriwijaya Faculty of Public Health issued a Certificate of Research Ethics with No. 187/UN9.FKM/TU.KKE/2021

\section{Result}

Ninety-four respondents participated in the pre-test $(37.60 \%)$, sixty of them join the post-test stage (63.83\%), and thirty-three respondents met the final screening qualifications. The respondents were aged between 60-78 years; more women than men (66.7\%); multiethnic; primarily undergraduate and postgraduate education (51.5\%); most of them were not working/retired (72.7\%); mostly married $(72.7 \%)$ and had at least 1 type of degenerative disease (72.7\%). Hypertension was the most common degenerative disease $(35.6 \%)$, followed by arthritis $(26.7 \%)$. The majority of respondents said they did not need help with their daily activities (90.9\%). Table 1 displayed the 
characteristics of the respondents.

The average differences between the results of the pre-test (baseline) and post-test scores were calculated after the intervention program was carried out for one month, as shown in Table 2. The difference between average pre-test and post-test scores showed significant results ( $\mathrm{p}$-value 0.041). According to the results of the total assessment of each aspect or domain in Table 3, the psychological domain (p-value 0.025), the social domain (p-value 0.033), and the environmental domain (p-value 0.033) all showed a significant increase in value (p-value 0.034.) As per Table 4, there was a significant increase in pre-test and post-test results after the participants received virtual health education, as well as a significant improvement in the aspect of enjoying life (p-value 0.001), the ability to concentrate (p-value 0.012), and the sense of security in everyday life after the interventions ( $p$-value $0.017)$.

Table 1. Characteristics of respondents based on age, gender, ethnic, education, occupation, marital status, number and types of degenerative diseases and assistance needs $(n=33)$

\begin{tabular}{|c|c|c|c|}
\hline \multirow{2}{*}{ No. } & \multirow{2}{*}{ Variables } & \multirow{2}{*}{$\begin{array}{c}\text { Frequency } \\
\mathbf{n}=\mathbf{3 3}\end{array}$} & \multirow{2}{*}{$\frac{\text { Percentage }}{\%}$} \\
\hline & & & \\
\hline \multirow[t]{3}{*}{1} & Age (years old) & & \\
\hline & $60-67$ & 19 & 57.60 \\
\hline & $68-78$ & 14 & 42.40 \\
\hline \multirow[t]{3}{*}{2} & Gender & & \\
\hline & Male & 11 & 33.30 \\
\hline & Female & 22 & 66.70 \\
\hline \multirow[t]{5}{*}{3} & Ethnic & & \\
\hline & Chinese & 20 & 60.60 \\
\hline & Palembang & 3 & 9.10 \\
\hline & Minang & 2 & 6.10 \\
\hline & Javanese & 8 & 24.20 \\
\hline \multirow[t]{5}{*}{4} & Level of Education & & \\
\hline & Junior High School & 3 & 9.10 \\
\hline & Senior High School & 8 & 24.20 \\
\hline & Diploma & 5 & 15.20 \\
\hline & Undergraduate and Postgraduate & 17 & 51.50 \\
\hline \multirow[t]{7}{*}{5} & Occupation & & \\
\hline & Not working/retired & 24 & 72.70 \\
\hline & Government employee & 2 & 6.10 \\
\hline & Entrepreneur/Self employee & 4 & 12.10 \\
\hline & Private employee & 1 & 3.00 \\
\hline & Consultant & 1 & 3.00 \\
\hline & Doctor & 1 & 3.00 \\
\hline \multirow[t]{3}{*}{6} & Marital Status & & \\
\hline & Married & 24 & 72.70 \\
\hline & Single parent/widower/widow & 9 & 27.30 \\
\hline \multirow[t]{4}{*}{7} & Number Degenerative Diseases & & \\
\hline & 1 degenerative disease & 24 & 72.70 \\
\hline & 2 degenerative diseases & 6 & 18.20 \\
\hline & $>2$ degenerative diseases & 3 & 9.10 \\
\hline \multirow[t]{9}{*}{8} & Types of degenerative diseases & & \\
\hline & Diabetes & 6 & 13.30 \\
\hline & Hypertension & 16 & 35.60 \\
\hline & Heart Disease & 3 & 6.70 \\
\hline & Kidney failure & 1 & 2.20 \\
\hline & Arthritis & 12 & 26.70 \\
\hline & Cancer & 3 & 6.70 \\
\hline & Cataract & 1 & 2.20 \\
\hline & Hypercholesterol & 3 & 6.70 \\
\hline \multirow[t]{3}{*}{9} & The Need for Assistance & & \\
\hline & No & 30 & 90.90 \\
\hline & Yes & 3 & 9.10 \\
\hline
\end{tabular}


Table 2. The differences between pretest and posttest results after the intervention program $(n=33)$

\begin{tabular}{|c|c|c|c|c|}
\hline Results & Minimum & Maximun & Mean & $p$-value** \\
\hline Pre-test (baseline) & & & $61.90 \pm 7.84$ & \multirow{4}{*}{0.041} \\
\hline \multirow{3}{*}{ Post-test (follow-up) } & 50.00 & 84.50 & & \\
\hline & & & $64.54 \pm 9.48$ & \\
\hline & 48.50 & 90.75 & & \\
\hline
\end{tabular}

Table 3. The differences between pretest and posttest results in the 4 domains of quality of life after the intervention program $(n=33)$

\begin{tabular}{|c|c|c|c|c|c|c|c|c|c|c|c|}
\hline \multirow{4}{*}{ No } & \multirow{4}{*}{$\begin{array}{c}\text { Virtual } \\
\text { Education }\end{array}$} & \multirow{4}{*}{$\begin{array}{c}\text { Follow-up } \\
\text { Result } \\
\text { (Post- } \\
\text { test) }\end{array}$} & \multirow{2}{*}{\multicolumn{4}{|c|}{ Quality of Life }} & \multirow{3}{*}{\multicolumn{2}{|c|}{ Total }} & \multirow{4}{*}{$\begin{array}{c}p- \\
\text { value }\end{array}$} & \multirow{4}{*}{ OR } & \multirow{4}{*}{$95 \% \mathrm{CI}$} \\
\hline & & & & & & & & & & & \\
\hline & & & \multicolumn{2}{|l|}{ Poor } & \multicolumn{2}{|c|}{ Good } & & & & & \\
\hline & & & $\mathbf{n}$ & $\%$ & $\mathbf{n}$ & $\%$ & $\mathbf{n}$ & $\%$ & & & \\
\hline \multirow{3}{*}{1} & Physical & & & & & & & & & & $2.877-$ \\
\hline & Domain & Poor & 8 & 80 & 2 & 20 & 10 & 100 & 0.001 & 19.000 & 125.481 \\
\hline & & Good & 4 & 17.4 & 19 & 82.6 & 23 & 100 & & & \\
\hline \multirow{3}{*}{2} & Psychological & & & & & & & & & & $2.776-$ \\
\hline & Domain & Poor & 9 & 100 & 0 & 0 & 9 & 100 & 0.000 & 8.000 & 23.056 \\
\hline & & Good & 3 & 12.5 & 21 & 87.5 & 24 & 100 & & & \\
\hline \multirow{3}{*}{3} & & & & & & & & & & & $0.234-$ \\
\hline & Social Domain & Poor & 12 & 60 & 8 & 40 & 20 & 100 & 0.001 & 0.400 & 0.684 \\
\hline & & Good & 0 & 0 & 13 & 100 & 13 & 100 & & & \\
\hline \multirow{3}{*}{4} & Environmental & & & & & & & & & & $1.501-$ \\
\hline & Domain & Poor & 6 & 75 & 2 & 25 & 8 & 100 & 0.015 & 9.500 & 60.107 \\
\hline & & Good & 6 & 24 & 19 & 76 & 25 & 100 & & & \\
\hline
\end{tabular}


Table 4. The whoqol-bref score increase in the charitas senior citizen virtual club participants after the interventions $(\mathrm{n}=33)$

\begin{tabular}{|c|c|c|c|c|c|}
\hline \multirow[b]{2}{*}{ No } & \multirow[b]{2}{*}{ Domains } & \multirow[b]{2}{*}{ Facets } & \multicolumn{2}{|l|}{ Score } & \multirow[b]{2}{*}{$p$-value } \\
\hline & & & $\begin{array}{c}\text { Pre- } \\
\text { Test } \\
\text { (range) }\end{array}$ & $\begin{array}{l}\text { Post- } \\
\text { Test } \\
\text { (range) }\end{array}$ & \\
\hline 1 & \multirow[t]{9}{*}{ Physical } & How would you rate your quality of life? & $4(2-5)$ & $4(3-5)$ & 0,744 \\
\hline 2 & & How satisfied are you with your health? & $3(1-4)$ & $3(1-5)$ & 0,281 \\
\hline 3 & & $\begin{array}{l}\text { To what extent do you feel that physical pain } \\
\text { prevents you from doing what you need to } \\
\text { do? }\end{array}$ & $4(2-5)$ & $4(3-5)$ & 0,201 \\
\hline 4 & & $\begin{array}{l}\text { How much do you need any medical } \\
\text { treatment to function in your daily life? }\end{array}$ & $4(3-5)$ & $4(3-5)$ & 1,000 \\
\hline 5 & & $\begin{array}{l}\text { Do you have enough energy for everyday } \\
\text { life? }\end{array}$ & $3(2-5)$ & $3(1-5)$ & 0,62 \\
\hline 6 & & How satisfied are you with your sleep? & $3(1-5)$ & $4(1-5)$ & 0,206 \\
\hline 7 & & $\begin{array}{l}\text { How satisfied are you with your ability to } \\
\text { perform your daily living activities? }\end{array}$ & $4(1-4)$ & $4(1-5)$ & 0,361 \\
\hline 8 & & $\begin{array}{l}\text { How satisfied are you with your work } \\
\text { capacity? }\end{array}$ & $3(1-4)$ & $3(1-5)$ & 0,557 \\
\hline 9 & & How well are you able to get around? & $4(3-4)$ & $4(1-5)$ & 0,662 \\
\hline 10 & \multirow[t]{6}{*}{ Psychological } & How much do you enjoy life? & $3(2-4)$ & $4(3-5)$ & 0,001 \\
\hline 11 & & $\begin{array}{l}\text { To what extent do you feel your life to be } \\
\text { meaningful? }\end{array}$ & $3(3-5)$ & $4(2-5)$ & 0,201 \\
\hline 12 & & How well are you able to concentrate? & $3(2-4)$ & $3(2-5)$ & 0,012 \\
\hline 13 & & $\begin{array}{l}\text { Are you able to accept your bodily } \\
\text { appearance? }\end{array}$ & $3(3-4)$ & $3(3-5)$ & 0,254 \\
\hline 14 & & How satisfied are you with yourself? & $4(1-5)$ & $4(3-5)$ & 0,677 \\
\hline 15 & & $\begin{array}{l}\text { How often do you have negative feelings } \\
\text { such as blue mood, despair, anxiety, } \\
\text { depression? }\end{array}$ & $4(2-5)$ & $4(2-5)$ & 0,414 \\
\hline 16 & \multirow[t]{3}{*}{$\begin{array}{l}\text { Social } \\
\text { Relationship }\end{array}$} & $\begin{array}{l}\text { How satisfied are you with your personal } \\
\text { relationships? }\end{array}$ & $3(3-5)$ & $4(3-5)$ & 0,211 \\
\hline 17 & & How satisfied are you with your sex life? & $3(1-4)$ & $3(1-4)$ & 0,211 \\
\hline 18 & & $\begin{array}{l}\text { How satisfied are you with the support you } \\
\text { get from your friends? }\end{array}$ & $3(3-5)$ & $4(3-5)$ & 0,051 \\
\hline 19 & \multirow[t]{8}{*}{ Environmental } & How safe do you feel in your daily life? & $3(2-4)$ & $3(2-5)$ & 0,017 \\
\hline 20 & & How healthy is your physical environment? & $3(3-4)$ & $4(2-5)$ & 0,263 \\
\hline 21 & & $\begin{array}{l}\text { Have you enough money to meet your } \\
\text { needs? }\end{array}$ & $3(2-5)$ & $3(2-5)$ & 0,263 \\
\hline 22 & & $\begin{array}{l}\text { How available to you is the information that } \\
\text { you need in your day-to-day life? }\end{array}$ & $3(3-5)$ & $4(3-5)$ & 0,071 \\
\hline 23 & & $\begin{array}{l}\text { To what extent do you have the opportunity } \\
\text { for leisure activities? }\end{array}$ & $3(2-5)$ & $3(2-4)$ & 0,712 \\
\hline 24 & & $\begin{array}{l}\text { How satisfied are you with the conditions of } \\
\text { your living place? }\end{array}$ & $4(3-5)$ & $4(3-5)$ & 1,000 \\
\hline 25 & & $\begin{array}{l}\text { How satisfied are you with your access to } \\
\text { health services? }\end{array}$ & $4(1-5)$ & $4(3-5)$ & 0,051 \\
\hline 26 & & How satisfied are you with your transport? & $4(3-5)$ & $4(3-4)$ & 0,263 \\
\hline
\end{tabular}




\section{Discussion}

The interventions provided at the Charitas Senior Citizens Virtual Club showed some improvements in the quality of life of the elderly with degenerative diseases. The influence of physical factors on quality of life has been widely studied before. The research was conducted in Indonesia by Jacob in Karubaga Village, Karubaga District, Tolikara Regency, Papua11 and Kosim (2015) on residents in Sentul Village, Sumbersuko District, Lumajang Regency ${ }^{12}$ showed that there was an influence of physical factors on the quality of life of the local population. While in the U.S., participation in at least

$300 \mathrm{~min} / \mathrm{week}$ of Lifestyle Light-intensity Physical Activity (LLPA) was associated with more favorable health outcomes 13 .

The interventions provided at the Charitas Senior Citizens Virtual Club provided several programs for the elderly with degenerative diseases. Brain exercise is beneficial for maintaining the elderly's ability by providing stimulation to the brain ${ }^{14}$. Brain vitalization exercise has been shown to have a significant effect on increasing the cognitive function of the elderly and reducing the stress level of the elderly in dealing with various life stressors ${ }^{15}$. Brain exercise can be done by the elderly at any time and will be more effective when done with optimal focus and concentration with proper scheduling and training15. Brain gym significantly reduced sleep disturbance and anxiety in the elderly after eight weeks of intervention $(p \text {-value }<0.001)^{16}$. Health education is the promotion in which specific aspects of old age can adapt to a healthy and active life. A study in Japan also found that an educational program focused on knowledge and exercise can improve the quality of life ${ }^{17}$. Health education through live streaming YouTube can increase the community knowledge, especially families with the elderly, to pay more attention to the health conditions of the elderly, both physical and psychosocial ${ }^{18}$. Regular meditation practice can improve telomere regulation, which is linked to both the aging process and the development of cancer19. By practicing meditation, you can help yourself recover from memory loss while also improving various aspects of your mental health that are essential for cognitive function 20 . Meditation practice can help reduce stress ${ }^{21}$ and lower blood pressure in people with hypertension 22,23. Music can also affect improving a person's quality of life ${ }^{24}$. Javanese karawitan traditional music improved the quality of life of the local elderly 25 . Community singing groups have a significant effect on mental health, anxiety and depression in the elderly 26. Singing was part of therapy for chronic respiratory disorders such as Chronic Obstructive Pulmonary Disease (COPD), bronchiectasis, interstitial lung disease, asthma, and respiratory arrest during sleep ${ }^{27}$. Regular karaoke singing practice could improve cognitive function in the elderly and could even help improve physical function, especially in sarcopenia28.

The interventions provided were for improvements in the quality of life of the elderly with degenerative diseases. Group discussions have improved the quality of life of patients with diabetes mellitus 29 . The opportunity to share experiences and receive feedback showed an improvement in the quality of life of diabetic patients after a group discussion with instructive feedback. Unhealthy behaviors such as smoking showed that emotional support and information through online social groups (such as WhatsApp and Facebook) could support relapse prevention ${ }^{30}$. Participants in the online social group shared their views and personal experiences (55.5\%), provided encouragement $(28.7 \%)$ and shared knowledge and information (15.8\%) with other participants.

The study does have some limitations. Respondents over the age of 60 may be biased due to their age range. Although technical instructions are provided, respondents may be frustrated by the digital questionnaire application. Second, due to the rigorous exclusion to ensure that the criteria are met, there is a lack of sample size. A better study design with a control group will improve the study's ability to conduct a conclusive comparison.

\section{Conclusions}

There was a significant effect of the Charitas Group Virtual Health Education program on improving the quality of life of the elderly with degenerative diseases in the COVID-19 pandemic era, especially in the 
domains of Psychology, Social and Environment. Advanced technology that enables people to communicate and form virtual communities can revolutionize health promotion and support a paradigm shift from curative to preventive and promotive action to improve the quality of life of the elderly with degenerative diseases.

\section{Acknowledgement}

We would like to thank the Management of Charitas Group and Charitas Hospitals Foundation, which has allowed this research and all Charitas Senior Citizens Virtual Club members who have supported and collaborated in this study.

\section{References}

1. Kementerian Kesehatan RI 2020. Pedoman pencegahan dan pengendalian Coronavirus disease (COVID-19) revisi ke-5.; 2020. doi: $10.33654 /$ math.v4i3.272

2. Donovan NJ, Wu Q, Rentz DM, Sperling RA, Marshall GA, Glymour MM. Loneliness, depression and cognitive function in older U.S. adults. Int $\mathrm{J}$ Geriatr Psychiatry. 2017;32(5):564-573. doi:10.1002/gps.4495

3. Steinman MA, Perry L, Perissinotto CM. Meeting the care needs of older adults isolated at home during the COVID-19 pandemic. JAMA Intern Med. Published online 2020:819820. doi:10.1002/gps.4495

4. Kirkman MS, Briscoe VJ, Clark N, et al. Diabetes in older adults. Diabetes Care. 2012;35(12):2650-2664. doi:10.2337/dc121801

5. Boima V, Tetteh J, Yorke E, et al. Older adults with hypertension have increased risk of depression compared to their younger counterparts: Evidence from the World Health Organization study of Global Ageing and Adult Health Wave 2 in Ghana. J Affect Disord. 2020;277(May):329-336. doi:10.1016/j.jad.2020.08.033

6. Sy SL, Munshi MN. Caring for older adults with diabetes during the COVID-19 pandemic.
JAMA Intern Med. Published online 2020:E12. doi: $10.2337 / \mathrm{dc} 12-1801$

7. Li P, Chen L, Liu Z, et al. Clinical features and short-term outcomes of elderly patients with COVID-19. Int J Infect Dis. 2020;97:245-250. doi:10.1016/j.ijid.2020.05.107

8. Wang H, Li T, Gauthier S, et al. Coronavirus epidemic and geriatric mental healthcare in China: How a coordinated response by professional organizations helped older adults during an unprecedented crisis. Int Psychogeriatrics. 2020;32(10):1117-1120. doi: $10.1017 /$ S1041610220000551

9. Gao Z, Lee JE, McDonough DJ, Albers C. Virtual reality exercise as a coping strategy for health and wellness promotion in older adults during the COVID-19 pandemic. J Clin Med. 2020;9(1986):1-10. doi:10.3390/jcm9061986

10. Orley J. WHOQOL-BREF: Introduction, administration and generic version.; 1996. http: / / apps.who.int/iris/bitstream/handle/1 0665/63529/WHOQOLBREF.pdf?sequence $=1 \&$ is Allowed $=y$

11. Jacob DE, Sandjaya S. Faktor faktor yang mempengaruhi kualitas hidup masyarakat Karubaga district sub district Tolikara propinsi Papua. J Nas Ilmu Kesehat. 2018;1(Juni):116.

12. Kosim N, Istiyani N, Komariyah S. Faktor yang mempengaruhi kualitas hidup penduduk di Desa Sentul Kecamatan Sumbersuko Kabupaten Lumajang. Artik Ilm Mhs. Published online 2015:1-6.

13. Loprinzi PD, Lee H, Cardinal BJ. Evidence to support including lifestyle light-intensity recommendations in physical activity guidelines for older adults. Am J Heal Promot. 2015;29(5):277-284. doi:10.4278/ajhp.130709-QUAN-354

14. Yuliati Y, Hidaayah N. Pengaruh senam otak (brain gym) terhadap fungsi kognitif pada lansia di rt 03 rw 01 Kelurahan Tandes Surabaya. J Heal Sci. 2017;10(1):88-95. doi:10.33086/jhs.v10i1.149 
15. Azizah LM, Martiana T, Soedirham O. The improvement of cognitive function and decrease the level of stress in the elderly with brain gym. Int $\mathrm{J}$ Nurs Midwifery Sci. 2017;1(1):26-31.

doi:10.29082/ijnms/2017/vol1.iss 1.33

16. Effendy E, Prasanty N, Utami N. The effects of brain gym on quality of sleep, anxiety in elderly at nursing home care case Medan. Open Access Maced J Med Sci. 2019;7(16):25952598. doi:10.3889/oamjms.2019.397

17. Mallmann DG, Galindo Neto NM, De Carvalho Sousa J, Vasconcelos EMR. Health education as the main alternative to promote the health of the elderly. Cienc e Saude Coletiva. 2015;20(6):1763-1772. doi:10.1590/141381232015206.02382014

18. Melia S, Triana H, Prasetyo YA. Edukasi kesehatan lansia dan adaptasi kebiasaan baru melalui media live streaming Youtube. In: Seminar Nasional Semnas LPPM Universitas Muhammadiyah Purwokerto. ; 2020:150-153.

19. Conklin QA, Crosswell AD, Saron CD, Epel ES. Meditation, stress processes, and telomere biology. Curr Opin Psychol. 2019;28:92-101. doi:10.1016/j.copsyc.2018.11.009

20. Khalsa DS. Stress, meditation, and Alzheimer's disease prevention: Where the evidence stands. J Alzheimer's Dis. 2015;48(1):1-12. doi:10.3233/JAD-142766

21. Pramudhanti H, Mabruri MI. Efektivitas meditasi transedental untuk menurunkan stres pada penderita hipertensi. Intuisi $\mathrm{J}$ Psikol Ilm. 2017;9(2):1-13.

22. Asmarani FL. Pengaruh terapi meditasi terhadap kejadian hipertensi pada lansia di BPSTW Provinsi DI Yogyakarta unit Budi Luhur Kasihan Bantul. J Keperawatan Respati Yogyakarta. 2018;5(1):327-330. http://nursingjurnal.respati.ac.id/index.php/ JKRY / index

23. Sudiarto, Wijayanti R, Sumedi T. Pengaruh terapi relaksasi meditasi terhadap penurunan tekanan darah pada lansia dengan hipertensi di wilayah binaan Rumah Sakit Emanuel Klampok Banjarnegara. Soedirman J Nurs. 2017;2(3):118-126.

24. Coffman DD. Music and quality of life in older adults. Psychomusicology A J Res Music Cogn. 2002;18(1-2):76-88. doi:10.1037/h0094050

25. Oktiawati A, Rakhman A, Khodijah K. Musik Karawitan Jawa meningkatkan kualitas hidup lansia di Kelurahan Kagok Kecamatan Slawi Kabupaten Tegal. Bhamada J Ilmu dan Teknol Kesehat. 2017;8(2):71-77.

26. Coulton S, Clift S, Skingley A, Rodriguez J. Effectiveness and cost-effectiveness of community singing on mental health-related quality of life of older people: Randomised controlled trial. $\mathrm{Br} \mathrm{J}$ Psychiatry. 2015;207(3):250-255.

doi:10.1192/bjp.bp. 113.129908

27. Lewis A, Cave P, Stern M, et al. Singing for Lung Health - A systematic review of the literature and consensus statement. npj Prim Care Respir Med. 2016;26(June):1-8. doi:10.1038/npjpcrm.2016.80

28. Miyazaki A, Mori H. Frequent karaoke training improves frontal executive cognitive skills, tongue pressure, and respiratory function in elderly people: Pilot study from a randomized controlled trial. Int $J$ Environ Res Public Health. 2020;17(4):12-14. doi:10.3390/ijerph17041459

29. Afshar M, Memarian R, Mohammadi E. The effect of group discussion on the quality of life and $\mathrm{HbA1c}$ levels of adolescents with diabetes. Iran Red Crescent Med J. 2014;16(8):1-5. doi:10.5812/ircmj.21110

30. Cheung YTD, Chan CHH, Wang MP, Li HCW, Lam TH. Online Social Support for the Prevention of Smoking Relapse: A Content Analysis of the WhatsApp and Facebook Social Groups. Telemed e-Health. 2017;23(6):507516. doi:10.1089/tmj.2016.017 
